\title{
Use of Nominee Arrangement by Foreigner in Land Procurement and Land Ownership Principle in Indonesia
}

\author{
Ana Silviana $^{1}$, Yos Johan Utama ${ }^{2}$, Dini Anggreini ${ }^{3}$ \\ \{email: silvianafhundip@gmail.com ${ }^{1}$,email: yosjohanutama@yahoo.com², \\ email: dinianggreini@gmail.com ${ }^{3}$.\} \\ Diponegoro University, J1.Prof.H.Soedarto, S.H., Tembalang, Tembalang, Kota Semarang, Jawa \\ Tengah 50275 Indonesia $^{1}$ \\ Diponegoro University, Jl.Prof.H.Soedarto, S.H., Tembalang, Tembalang, Kota Semarang, Jawa \\ Tengah 50275 Indonesia $^{2}$ \\ Diponegoro University, Jl.Prof.H.Soedarto, S.H., Tembalang, Tembalang, Kota Semarang, Jawa \\ Tengah 50275 Indonesia $^{3}$
}

\begin{abstract}
Nationality Principle in Land Law states that only Indonesian citizens can own land in the Republic of Indonesia territory. In practice, many foreigners can own the Hak Milik (Freehold Title) land through the nominee agreement as well as the nominee arrangement, especially in Bali. The implementation of the agreement has provoked many disputes in court. The purpose of this study is to find out the reason of the use of nominee arrangement in the ownership of Hak Milik (Freehold Title) land by foreigners in Indonesia, and to find out the legal effect of the use of nominee arrangement related to the provisions of Article 26 paragraph (2) of Undang-Undang Pokok Agraria/UUPA (Basic Agrarian Law). The approach method used in this research is the doctrinal approach. In doctrinal research, a law is conceptualized and developed based on the doctrine adopted by the conceptual and the developer. In this study, the law is conceived as the rule of law. The data used are secondary data obtained from library research. This research is a case study of Court Decision Number 82/Pdt.G/2013/PN.DPS, which will be analyzed normatively qualitative. Nominee Arrangement is widely used, particularly in Bali, to deviate land law policy which prohibits foreigners owning Hak Milik (Freehold Title) land in Indonesia as the nationality principle in National Land Law.
\end{abstract}

\section{Introduction}

Indonesian land law that follows the Nationality principal determines that foreigners cannot own land in Indonesia either for Hak Milik/ HM (Freehold Title), Hak Guna Bangunan/ HGB (Building Rights Title) or Hak Guna Usaha/ HGU (Cultivation Rights Title) status [1]. The transfer of land rights to foreigners through trade, or exchange, directly or indirectly, is null by law [1].

The practice of using nominee arrangement nowadays is not only related to borrowing the name as a shareholder in Indonesian Corporation, but also in the land ownership in Indonesia, and this is rampant especially in Bali, to deviate from the prevailing law [2]. Why the nominee arrangement widely used in land ownership and what the legal consequences will be examined in this study.

\section{Methodology}


The approach method used in this research is the doctrinal approach/normative juridical. In this study, the law is conceived as the rule of law. Doctrinal/normative law research is a proper research method which is conducted by inspecting references sourced from secondary data.

The data obtained was analyzed qualitatively normatively by using deductive thinking method, that is a general fact-based mindset, then drawn into specific conclusions to reach clarification of the issues discussed [3].

\section{Findings}

\subsection{The reason for the use of nominee arrangements in HM (Freehold Title) ownership of land by foreigners in Bali, Indonesia}

In line with the economic development in Indonesia, the need for land regarding the need for physical development is increasing. The land is not only needed for shelter, but also a place to do business as well as to be used as collateral to get bank loans, for business purposes, leases, and buy-and-sell.

Entering the era of globalization, the possibility of open opportunities for foreign investors to invest and open businesses, as well as to own property in Indonesia is highly increasing [3]. About the need for land for business development facilities, it must be subject to the applicable laws in Indonesia, especially Land Law.

Land, in the juridical sense, is a part of the earth called the surface of the earth (land), which can be given to and owned by people, alone or together with others and legal entities (Article $4 U U P A$ ). The possibility of land ownership by foreigners and foreign legal entities has been regulated by the UUPA in Article 42 that: "Those who have the Hak Pakai (Right to Use) are: Indonesian citizens, foreigners living in Indonesia, legal entities established under Indonesian law and domiciled in Indonesia, and foreign legal entity which has the representative in Indonesia".

UUPA embraces the Nationality principle, that: "Only Indonesian citizens have the right to the land or that may relate to the earth and space, by not distinguishing between Indonesian men and women, indigenous or not." This principle stipulates that foreigners cannot own land in Indonesia; the transfer of property to foreigners is prohibited by the threat of nullification by law. (Article 9, Article 21 paragraph (1) just Article 26 paragraph (2) UUPA) [4].

Furthermore, the provisions on Hak Pakai (Right to Use) are regulated by Government Regulation no. 40 of 1996 concerning Hak Guna Usaha (Cultivation Right Title), Hak Guna Bangunan (Building Rights Title) and Hak Pakai atas Tanah (Right to Use Title on Land). UUPA determines that foreigners (WNA) domiciled in Indonesia and foreign legal entities with representation in Indonesia may be granted a Right to Use, and the Right to Use to foreigners is a Right to Use which has a specified period.

However, in practice, there are still many legal actions taken by foreigners in cooperation with Indonesian citizens by making voluntary agreements to violate the applicable laws. Among various ways, they use the usual way of applying for "nominee arrangement" ownership [4]. Such a method is prohibited by Article 33 paragraph (1) of Law no. 25 of 2007 on Capital Investment, that: "prohibiting domestic investors and foreign investors from entering into agreements and statements confirming the ownership of shares in limited liability companies for and on behalf of others."

The nominee agreement is a person or entity which is a legal owner of a property or 
income for the benefit or based on a trustee who becomes the owner of the property or the party who benefit the income [5]. Nominee arrangement has been frequently made in Bali, in the ownership of the freehold title land by foreigners, as the case to be studied in this study which has obtained a decision of permanent legal force (in Kracht van gewijsde). The disputed object of this case is Freehold title land located in KerobokanKelod, North Kuta, Badung Bali, on which stands a Villa building called "Subaliku Villa." Nominee arrangement has been made by Susan Eileen Mather (foreigner) with I Nyoman Sutapa (Indonesian), domiciled in Bali, on purchasing land in Bali which will be built a Villa called Subaliku Villa

One of the nominee arrangement agreements is an agreement made by Susan Eileen Mather (Foreigner) with I NyomanSutapa (Indonesian Citizen) in the case of Decision of the District Court Number 82/Pdt.G/2013/PN.DPS, there are two types of agreements made, namely the first agreement (Nominee arrangement) and followed by another agreement (KuasaJual/Power of Attorney to Sell). In 1998, Susan Eileen M bought Hak Milik(Freehold Title) land in KerobokanKelod area, North Kuta, Badung Bali. Since foreigners were not allowed to own Hak Milik (Freehold Title) land, an agreement was made with I NyomanSutapa so that Susan borrowed only her name to be included in the Hak Milik (Freehold Title) certificate later, which assured Susan Eileen Mather that her assets would be safe with I NyomanSutapa. For that matter, an agreement was made before a Notary stating that the entire purchase of the land came from Susan Eileen Mather and ultimately recognized the ownership of the land is in the hands of Susan Eileen Mather. In addition to making the notarial statement, I Nyoman also signed a Power of Attorney for Sale from I Nyoman to Susan EM. Afterward, on the land of SHM (Freehold Title Certificate), No. $3590 /$ Kerobokan of $1500 \mathrm{~m} 2$ was built Villa which was then named as Subaliku Villa.

In 1998, Susan Eileen M bought Hak Milik (Freehold Title) land in KerobokanKelod area, North Kuta, Badung Bali. Since foreigners were not allowed to own Hak Milik (Freehold Title) land, an agreement was made with I NyomanSutapa so that Susan borrowed only her name to be included in the Hak Milik (Freehold Title) certificate later, which assured Susan Eileen Mather that her assets would be safe with I NyomanSutapa. For that matter, an agreement was made before a Notary stating that the entire purchase of the land came from Susan Eileen Mather and fully recognized the ownership of the land is in the hands of Susan Eileen Mather. In addition to making the notarial statement, I Nyoman also signed a Power of Attorney for Sale from I Nyoman to Susan EM. Afterwards, on the land of SHM (Freehold Title Certificate), No. 3590/Kerobokan of $1500 \mathrm{~m} 2$ was built Villa which was then named as Subaliku Villa.

On October 21, 2005, there was another agreement signing concerning the affirmation of money to buy and to build Subaliku Villa from Susan EM. The agreement also contained I NyomanSutapa's willingness to assist Susan EM to sell the Villa and the right of each party to seek buyer with the highest price agreed by Susan EM and me NyomanSutapa, as well as the profit-sharing when the Villa sold

On May 14, 2012, with Susan Eileen Mather knowing, I NyomanSutapa registered the land and the villa building on it to the property agent to help sell for Rp. 16.000.000.000 (Sixteen Billion Rupiah). Unbeknownst to Susan Eileen Mather, I NyomanSutapa sold the land to Farhat Said at Rp. 6,500,000,000, - based on Deed of Sale and Purchase Number 304/2012 dated August 6, 2012

Based on the legal acts committed by I Nyoman Sutapa, Susan Eileen Mather felt aggrieved, so she filed a lawsuit in Denpasar District Court. The lawsuit contained, among 
others, claim that the nominee agreement made on October 21, 2005, is declared LEGAL and has a binding legal force, and the sale made by I NyomanSutapa to Farhat Said with Deed of Sale and Purchase Number 304/2012, dated August 6, 2012, unbeknownst to Susan Eileen Mather is an unlawful act.

Based on the judge's consideration of this case, the Judge decided in case number 82/Pdt.G/2013/PN.DPS, stating the nominee arrangement was nullified by the law as it opposed to Article 21 UUPA and Article 1337 of Civil Code. The judge also stated that the purchasing and selling done between I NyomanSutapa with Farhat Said is an unlawful act which affected that the Sale and Purchase Agreement number 52, the agreement of Sale Authorization number 53 and Deed of Sale Number 304/2012 were also declared nullified.

The agreement made by Susan Eileen Mather with I NyomanSutapa is a nominee arrangement of the ownership of Freehold title land. The Nominee Agreement is an agreement that aims so that the real name and identity of the actual Party is unknown to the Government and the public, and the acknowledged and legal party is the nominee party. The characteristics of nominee agreement are the existence of two types of ownership, which are, legal ownership (de jure) and indirect ownership (de facto). The ownership of land rights in Indonesia, in this case, is Indonesian Citizen, who is registered as the legal owner and recorded in the land certificate and land book in the local Land Office. The nominee agreement must be signed between the nominee and the beneficiary as the basis of the nominee concept. In this case, the nominee receives a certain amount of fee as compensation for the use of his/her name and identity for the benefit of the beneficiary

The points of nominee agreement are that there are two types of ownership, which are, legal ownership (de jure) and indirect ownership (de facto). In relation to the ownership of land rights in Indonesia, in this case, the Indonesian Citizen is registered as the legal owner and recorded in the land certificate and land book in the local Land Office. In this case, the nominee receives a certain amount of fee as compensation for the use of his/her name and identity for the benefit of the beneficiary

Article 21 of UUPA states that those who can have Freehold Title are the Individual Indonesian and the Government-appointed legal entity. Indonesian Land Law does not allow foreigners to own Freehold Title land. Paragraph (3) of that article stipulates that a foreigner may still acquire a Freehold Title land by inheritance without a will, a mixture of property in marriage and the transfer of citizenship. However, such holdings are restricted to valid only for a period of 1 (one) year. Afterwards, it has to be released or transferred to parties qualified as holders of Freehold Title by law. The National Principle applied in Indonesian Land law also states that only Indonesian citizens can own land within Indonesia territory. Based on the provisions above, objectively, foreigners shall not own land in Indonesia either directly or indirectly

The agreement that uses Indonesian citizen as a trustee or nominee is a legal smuggling because its substance contradicts UUPA particularly Article 26 Paragraph (2) which reads: "Any sales, exchanges, grants, giving with testament and other acts intended to directly or indirectly transferring the property to a foreigner, to a citizen which in addition to her Indonesian citizenship having foreign nationality, or to a legal entity, unless determined by the Government referred to in Article 21 Paragraph (2), is null by the law and the land will belong to the country, provided that, the rights of another party that are still borne still persists and all payments received by the owner cannot be prosecuted "

Related to the case above, the agreement substance has violated the object clause of the agreement and therefore, is nullified.

Regarding the deed done by I Nyoman Sutapa who sold land and buildings with a lower 
price than what was agreed with Susan Eileen Mather, and that the sale was done without Susan Eileen Mather knowing, the Judge decided that such action was against the law. The verdict also affects the treaties to become illegitimate and has no legal forces and restores the position of land and buildings certified on behalf of I NyomanSutapaback. If it is based on UUPA Article 26 paragraph (2), then by the unauthorized sale and the cancellation of the nominee agreement, the right will be abolished and the land becomes the possession of the state. However, in this case, the Judge considers that I NyomanSutapa had used the nominee treaty for personal benefit and gain, thus harms Susan Eileen Mather as the defacto owner of the land. The building is an investment of Susan Eileen Mather thus it is proper that when returning the investment, the land and buildings were auctioned and the result is used to pay what has been invested by Susan Eileen Mather, that is for Rp.12.000.000.000, -

The agreement made by Susan Eileen Mather with I Nyoman which is a nominee arrangement followed by another agreement (Power of Attorney to Sell) with the authorizing of Hak Milik (Freehold Title) land by foreigners, has been proven as a law violate, by indirectly taking a notarial agreement [4].

The many uses of nominee arrangement in land ownership by foreigners in Indonesia, particularly Hak Milik (Freehold Title) is due to the safety and comfort the foreigners get when they get Hak Milik (Freehold Title) land. They think land with HakPakai (Right to Use) is not as strong as the one with Hak Milik (Freehold Title). Land with Hak Milik (Freehold Title) status provides legal certainty because it does not have expiry period, different with the land of HakGuna Usaha (Cultivation Right Title), HakGunaBangunan (Building Rights Title), HakPakaiatas Tanah (Right to Use Title on Land) and lease rights. Hak Milik (Freehold Title) is the strongest and the most fulfilled status compared to other land rights, which encourages foreigners to own land in Indonesia with Hak Milik (Freehold Title), as the legal certainty is guaranteed.

The prohibition of foreigners from possessing Hak Milik (Freehold Title) land is the reason for the foreigners to violate the law in order to have Hak Milik (Freehold Title) land in Indonesia through the nominee arrangement which is done in various ways, that are (1). A master agreement consisting of a land agreement and followed by a power of attorney; (2). Option agreement, that is how Indonesian Citizen gives an option to buy Hak Milik (Freehold Title) and buildings to foreigners because the foreigners; (3) fund the purchase of land HM and buildings. Lease Agreement; Power of Attorney to Sell [4].

3.2. The legal consequences of the use of nominee arrangement in Indonesian Land Law related to the provisions of Article 26 paragraph (2) of the UUPA (Basic Agrarian Law Act)

The legal consequence is the result caused by the law, towards an act committed by the subject of law. The legal consequence is an event caused by a factor, that is the act done by the subject of law, whether the act complies with the law, as well as those not complying with the law.

Indonesian Land Law regulates that principally, land ownership is only possible for Indonesian citizens, however, due to development and facilities for foreigners to invest and owns land in Indonesia, UUPA provides rights on land that foreigners can possess, that is HakPakai/HP (Right to Use)

An act of law that the basis is agreement must meet the validity requirements of the agreement. The agreement has regulated in the Kitab Undang-Undang Hukum 
Perdata/KUH Perdata (Civil Code) Article 1313, that agreement or consent is an action where one or more persons commit themselves to one or more persons. Legal consequences occur because of legal acts committed by legal subjects; one of them is the agreement done by private parties about certain things. By doing an agreement, a legal consequence has arisen, resulting in a right and duty to be performed by the concerned legal subjects in keeping the contents of the agreement.

Agreements by legal subjects may legally bind if they meet the requirements of the validity of the agreement which in the Civil Code in Article 1320 determine 4 (four) terms, which are:

1. Agreement.

Agreement occurs between those who commit themselves. The agreement is not only about agreeing to commit themselves but also agreeing to get the achievement. Each party has rights and obligations, that is the right to the achievements of the agreement and obligation to implement what is agreed in the agreed Agreement. [6]

\section{Competent}

Competent, according to the law in agreement making, is the person or legal entity that has the competence or ability to perform a legal act which is an act that will create legal consequences. Type of Incompetent persons in performing legal acts of agreeing/contract is regulated in Article 1330 of the Civil Code, which are: 1). People who are not adult yet; 2) people under supervision; 3). Women in matters regulated by law and all persons to whom the law has prohibited from making specific contracts. This provision has been removed by the Supreme Court based on Circular Letter No. 3/1962, stating that women are competent when they fulfill the requirement of being adult/eligible and not under individual supervision.

3. Specific matter/object or particular subject matter

In making a contract, the agreement points must be clear, thus the rights and obligations of the parties can be applied. Specific object means the accomplishment that is the subject of the contract. This is to confirm the nature and extent of the statement to which the parties are obliged. Non-binding statements, it may be determined by the nature and extent of the parties' obligations to be non-binding (nullified by the law). Achievement is a contractual legal obligation that must be specific or at least can be determined, so it is clear what rights and obligations of the contracting parties [3].

4. Causes that are not prohibited

The cause or causa refers to the existence of the physical relationship, which becomes the objective of the parties to close the contract or what the parties wish to achieve at the time of contracting. Criteria or size of cause or causa are not prohibited i.e., 1). The contract should not be against the law; 2). The contract should not discriminate against ethics; 3 ). Contracts should against public order [7]. The first and second requirement can be referred as subjective requirements and if there is a defect of the will or there is no fulfillment of the two conditions, that is agreed and competent, then it has the legal consequence that is an agreement cancellation. The legality of the third and fourth treaties are the terms of the objective agreement. The legal consequences if the two conditions are not fulfilled are null and void, which means that the agreement has not been taken for granted. Therefore, the parties are not bound by the agreement, so that each party cannot demand the implementation of the agreement because the agreement as the legal basis did not exist since the beginning.

According to Agreement Law, there are two types of agreements, i.e.: 
1. Statutory agreement (nominated), is an agreement which has with its name, that the agreement is regulated and named by the legislator, based on the most common type occurred;

2. Non-statutory agreement (innominate), is an agreement that is not regulated in the Civil Code, but the community regulation.

Related to this research, the use of the nominee arrangement agreement is an agreement that belongs to the non-statutory agreement (innominate), because this agreement is not explicitly regulated in the Civil Code and arises from the principle of contract freedom, so there is no specific regulation for this.

Etymologically, a nominee is a party that holds something over for the benefit of another party and channels the money earned on the ownership of a right for the benefit of another party [6]. Hence, a nominee means that the person is acting for the benefit of others in a limited way, parties that are legally registered for the benefit of others or those who receive and distribute the profits to other parties. In the context of Freehold title land ownership in Indonesia, it generally means that: "An engagement between parties to which one party agrees to control over the land with the status of Freehold Title with the rights attached to the land (nominee), for and on behalf of, as well as the interests of the other (principal)".

Several types of nominee agreements used in the acquisition of Hak Milik (Freehold Title) land act as if they were not violating the prevailing laws because they were not in the form of the land rights transfer. However, if the contents of the nominee agreement are thoroughly examined, then the nominee agreement is indirectly aimed at transferring the land of property rights to a foreigner. (Article 26 paragraph (2) UUPA). The nominee agreement is used because it only wants to economically profit the parties concerned. The parties agree on the contents of the agreement, but do not consider the material truth. For them, practical considerations are more important than their juridical judgment. The agreement with the use of power, with the Indonesian citizen as a trustee or nominee, is a legal violation because its substance is contradictory to the UUPA, particularly Article 26 paragraph (2). The legal consequences are null and void it because of the law and the landfall to the state, provided that the other parties who burden it remain and all payments received by the owner cannot be prosecuted again. In other words, the substance of the nominee agreement violates the terms of the objective of the agreement and therefore is void.

The legal consequences of violating the objective agreement terms are that the agreement becomes null and void due to the violation of the agreement as prohibited by the Law. The legal consequences of Article 26 paragraph (2), UUPA are to null and to void it because the law and the land go to the country, provided that the other parties who burden it remain and all payments received by the owner cannot be prosecuted again. In other words, the substance of the nominee agreement violates the terms of the objective of the agreement and therefore is void.

The civil case in this study is the lawsuit of Susan Eileen Mather, a foreigner who made an agreement with I NyomanSutapa (Indonesian) regarding the ownership Freehold land with case number 82/Pdt.G/2013/PN DPS decided by the Judge to grant some of Susan Eileen Mather's lawsuit, that is about the auction of the disputed object as stated in point 6 of the lawsuit. The judge stated that I NyomanSutapa (Indonesian, Defendant), Farhat Said (Defendant) and Eddy NyomanWinata (Defendant) have committed illegal acts because they have sold and bought land at a price far below market price. The judge ordered that the object of the dispute to be auctioned and the auction result were used to pay the investment 
that Susan Eileen Mather had made in Denpasar, that is, Rp. 12.000.000-.

According to the Land Law, the ownership of Freehold land through a nominee arrangement is a legal smuggling and it violates the objective agreement terms (Article 1320 Civil Code) because the substance violates the requirements for which the law violates and then the legal consequences are null and void due to law. This means that the law act never happened and returned to its original state. In making nominee agreement, herein it has violated the provisions of Article 26 paragraph (2) of UUPAjo Article 9 of UUPA.

Sociologically and economically, the Freehold purchase using nominee agreement occurred in 1998, and this civil dispute arose only in 2013. It means, the process of the land rights transfer that occurred since 15 (fifteen years ago) brought the consequences that the situation changes very quickly. The possibility to find the original seller would be undoubtedly tricky due to their existence. Based on the consideration that Susan EM has invested in Indonesia and economically participated in development in Indonesia especially in Denpasar, the Judge decided to auction the disputed object and the auction result was used to restore the investment done by Susan Eileen Mather in Bali.

The legal act of acquiring land by foreigners through nominee arrangement will remove the sovereignty of Indonesian citizens to own land in Indonesia, as well as smuggle Indonesian rule of law. Law smuggling by foreigners to own and control land rights in Indonesia undermines the sovereignty of Indonesia to control the land for the prosperity of Indonesian people. The country's task to develop the land for Indonesian people's welfare (Article 33 paragraph (3) of the 1945 Constitution) will not be established, but instead, the land will give prosperity for foreigners to be able to control land in Indonesia.

Law enforcement of the rule that only Indonesian can own land in Indonesia should be implemented. If this is left unchecked, there is this possibility when land in Indonesia or most of Indonesia is dominated by foreigners, and consequently, the purpose of land for the welfare and prosperity of Indonesian people will not be established. What will happen is, Indonesian people will become passengers or tenants on their own homeland. The greatest hope in the hands of a Judge in deciding cases related to foreigners with land ownership in Indonesia must be returned to the principle of nationality, that only Indonesian citizens can own land in Indonesia.

\section{Conclusion}

The legal act of acquiring land by foreigners through a nominee arrangement will remove the sovereignty of Indonesian citizens to own land in Indonesia and will violate Indonesian rule sovereignty. The reason why foreigner chooses the nominee arrangement is to have the more legal certainty of land ownership with Hak Milik (Freehold Title) which according to the Regulation, foreigners cannot have the Hak Milik (Freehold Title) land.

The background of the use of the nominee arrangement in the Freehold land ownership by Foreigners in Indonesia, especially in the civil case research in Bali, is the existence of legal provisions that prohibit foreigners to have the right to land in Indonesia in Agrarian/Land Law in accordance with the nationality principle in Land Law of Indonesia, and the assumption that the most guaranteed of legal certainty right is Freehold Title. Indonesian citizens as nominees and foreigners act as beneficiaries. Finally, the provisions of Article 9, Article

The legal consequences of the use of nominee arrangement in Indonesian Land Law related to the provision of Article 26 paragraph (2) of UUPA is determined void by law. 
Although subjectively there is an agreement by the nominee and beneficiary parties, the nominee agreement does not meet the material requirement because there is a violated requirement that is the contents of the provisions of Articles 9, 21 and Article 26 paragraph (2) UUPA. Freehold title land cannot be owned and transferred to foreigners either directly or indirectly. If this happens, the consequences are for the agreement becomes null and void by law.

\section{References}

[1] L. Bakker and S. Moniaga, "The space between: Land claims and the law in Indonesia," Asian J. Soc. Sci., vol. 38, no. 2, pp. 187-203, 2010.

[2] A. Fagertun, "Waves of dispossession: The conversion of land and labor in Bali's recent history," Soc. Anal., vol. 61, no. 3, pp. 108-125, 2017.

[3] A. Zoomers, "Globalisation and the foreignisation of space: seven processes driving the current global land grab," J. Peasant Stud., vol. 2, no. September 2012, pp. 37-41, 2010.

[4] M. E. Gold and R. B. Zuckerman, "Indonesian Land Rights and Development," Columbia J. Asian Law, vol. 1, p. 28, 2014.

[5] F. Jordan, "Disclosure of Beneficial Ownership and Control in Indonesia: Legislative and Regulatory Policy Options for Sustainable Capital Markets," Paris, 2013.

[6] R. Ming Kirk Tan, "Restrictions on the foreign ownership of property: Indonesia and Singapore compared," J. Prop. Invest. Financ., vol. 22, no. 1, pp. 101-111, 2004.

[7] T. Firman, "Major issues in Indonesia's urban land development," Land use policy, vol. 21, pp. $347-355$, Oct. 2004. 